\title{
LEGITIM GEOPOLITIKA VAGY NAGYHATALMI IDEOLÓGIA? - 150 ÉVE SZÜLETETT KARL HAUSHOFER
}

\author{
NAGY MIKLÓS MIHÁLY - DÖVÉNYI ZOLTÁN \\ LEGITIMATE GEOPOLITICS OR THE IDEOLOGY OF A GREAT POWER? \\ - ON THE OCCASSION OF KARL HAUSHOFER'S $150^{\text {th }}$ BIRTHDAY
}

\begin{abstract}
The present study has been written to commemorate the $150^{\text {th }}$ birthday of Karl Haushofer, the founder of classical German geopolitics. In terms of its theses, Haushofer's practical political geography was academic and was based primarily on Friedrich Ratzel's ideology. Haushofer considered it "legitimate geopolitics" from this aspect. Fascist state ideology adopted several concepts from Haushofer's system, but it applied these concepts with political meaning that was not originally intended. Thus, the theses of Haushofer and his colleagues quickly lost their credibility. In the end, the political system smeared his name and destroyed his family. The authors of the study remember Karl Haushofer by exploring the academic sources of his geopolitics, and by revealing this German geographer and general's ideas about "legitimate geopolitics," as well as his detachment from political geography. In terms of methodology, the study relies on the latest research findings and on Haushofer's original texts. In terms of sources, the authors demonstrate that geopolitics was not only impacted by the well-known works of Friedrich Ratzel and Rudolf Kjellén, but also by Carl Ritter's work and a number of philosophers as well. The study also examines Karl Haushofer's life and career while providing information about the social and academic influences that led to the establishment of "legitimate geopolitics."
\end{abstract}

Keywords: Karl Haushofer, geopolitics, legitimate geopolitics, the history of science, political ideology

\section{Bevezetés}

KARL HAUSHOFER utolsó, egyben egész életmúvét tudatosan lezáró tanulmányát a világháborút követően, a nürnbergi pert előkészítő amerikai szakemberek felszólítására írta, Apologie der deutschen Geopolitik (1946) címmel. A tanulmány kéziratát, amelyet az általa kidolgozott eszmerendszer védelmében, egyben az azzal kapcsolatos tévképzetek eloszlatására készített, 1945. november 2-án adta át kihallgatóinak. (SEIDT, H.-U. 2002) Ezek egyike, az amerikai geopolitikai szakértő, EDMUND A. WALSH a dolgozatot már a következó évben publikálta. (HAUshofER, K. 1946) A német tudós ennek hatását nem élhette meg: 1946. március 10-ról 11-re virradó éjszaka feleségével együtt - hetvenhét éves korában - öngyilkos lett. (TrolL, C. 1947; März, J. 1969) A tanulmányunk címében a geopolitikát minősítő adiectivumot Haushofer alkalmazta ebben az apológiai múvében. Így különböztette meg az ő és követői által tudományos alapon és hitelességgel folytatott geopolitikát és annak szakirodalmi termését a Harmadik Birodalom ideológiájában és propagandájában használt geopolitikai fogalomrendszertől. Utolsó dolgozatában HAUSHOFER ugyan elismerte, hogy a legitim geopolitika terminológiájának jelentős része beépült a fasiszta állampárt frazeológiájába,ám éppen az éles különbségtétellel azt is hangsúlyozta, hogy ennek - tartalmát tekintve - vajmi kevés köze volt a legitim geopolitikához. A Haushofer halála óta eltelt mintegy hét és fél évtizedben a legitim geopolitika kifejezése kikopott a tudományos közéletből, és ennek folyamatos arculatváltozásai, továbbá újabb irányzatainak kialakulása miatt helyét napjainkra a klasszikus geopolitika, valamint - Haushofer 
és a korabeli német iskola esetében - a klasszikus német geopolitika elnevezése foglalta el (Mező F. 2006; Nagy M. M. 2019; Nagy M. M.-DövÉNYi Z.-BÉKÉSI L. 2019).

Az általa alkalmazott szakmai kifejezés háttérbe szorulása azonban nem jelentette Haushofer és életmúve elfeledését is. Személye, munkássága, alkotásai immár háromnegyed évszázad óta foglalkoztatják úgy a geográfia tudománytörténetével, mint a múlt század kultúr-és politikatörténetével foglalkozó kutatókat. Históriai alakjának megítélése napjainkig kényes kérdés, és oly mértékben összefonódott tudományos tevékenységének értékelésével, hogy ez sokszor már zavarja,- mondhatnánk - egyenesen lehetetlenné teszi a tudós KARL HAUSHOFER elhelyezését a tudománytörténetben. Mindazonáltal életmúvének teljes körú számbavételét és megméretését nehezíti, hogy HAUSHOFER mint ember túl jelentôs személyiség és gondolkodó volt ahhoz, hogy mindenki számára elfogadható, egyszerúen értelmezhetó és a politológia, valamint a geográfiai tudománytörténetébe könnyen beilleszthetőként ragadjuk meg. Éppen a szellemi életben betöltött szerepe miatt - fóleg a Harmadik Birodalom határain túl - sokkal nagyobb jelentőséget tulajdonítottak neki a német és a náci politikai életben, mint amilyet valójában gyakorolt. A már említett apologetikus írásában maga is hangsúlyozta ezt, és ezen a véleményen volt kortársa, CARL TROLL német geográfus is, aki az általunk vizsgált témában közölt alaptanulmányában (Troll, C. 1947) önálló fejezetet szentelt Haushofernek és tragikus sorsának. A háborúban győztes hatalmak hírszerző szervezetei is a Harmadik Birodalom külpolitikájának determináns alakjaként próbálták meg HAUSHOFERt kihallgatni, és olyan naivul hangzó kérdésekben keresték szerepét, mint például: mennyiben volt közremúködő Hitler Mein Kampfjának megírásában, ő irányította-e a német külpolitika célmeghatározását, o indította-e útba Angliába a Harmadik Birodalom vezérének helyettesét, RudOLF Hesst, volt-e valami köze, sőt ő sugalmazta-e a japánok támadását az Amerikai Egyesült Államok ellen. (HAushofER, K. 1946; SEIDT, H.-U. 2002) A kihallgatása során vizsgált kérdések - a vallatók szakmai felkészületlenségén túl - azt is bizonyítják, hogy a világ - és a német társadalom zöme is - mit sem tudott arról, hogy HAUSHOFER 1938-tól kegyvesztett ember volt a Harmadik Birodalomban, sőt RUFOLF HESS angliai repülőútját követően a szellemi életben is a háttérbe szorult, családja egy részét letartóztatták, oot megfigyelték, és a háborút a dachaui koncentrációs táborban fejezte be.

Haushofer életét a kor- és pályatársak egy része tragikus embersorsnak élte meg. KARL HAUSHOFER egy müncheni értelmiségi család gyermekeként született 1869. augusztus 27-én. Az apja közgazdász professzor volt. Fia a gimnáziumi tanulmányait követően a bajor hadseregben kereste boldogulását; tiszt lett. Vezérkari akadémiát végzettként vezényelték hivatalos küldetésre Japánba, ahol az első világháborút megelőzően bő két évet töltött (1908-1910). Innen visszatérve jelentette meg - Dai Nihon címmel - katonai és politikai útleírását, amellyel felhívta magára a német szellemi élet figyelmét. Jóllehet még aktív katonatiszt volt és végigharcolta az elsô világháborút, amelyet tábornokként fejezett be, de érdeklődése már ekkor a tudományos élet felé fordult. 1913-ban ERICH VON DRYGALSKI professzornál doktorált: Japán felfedezés-történetéből, valamint politikai és katonaföldrajzából (EBELING, F. 1994). Elsősorban a világháború és a Második Birodalom széthullásának traumáját érzékelve építette ki azt a sajátos geopolitikai eszmerendszerét, amelynek kapcsán hamarosan világszerte ismert politikatudományi, valamint geográfiai gondolkodó lett. 1924-től ő és szellemi köre megjelentette a kor emblematikus szakmai folyóiratát, Zeitschrift für Geopolitik címmel. A weimari köztársaság időszakában, a német társadalom jelentős részéhez hasonlóan, Haushofer is a szélsőjobboldali erőkben látta hazája megmentőit, sőt 1933-tól egészen az 1938-ban történt kegyvesztéséig - a tudományos és a szellemi élet prominens alakjaként - támogatta a hitleri Nemzetiszocialista Német Munkáspárt (NSDAP) politikáját. HAUSHOFER azonban nem volt sem nemzetiszocialista, 
sem antiszemita: felesége zsidó származású volt. Fia, AlBRECHT HAUSHOFER szakképzett politikai geográfus lett, aktívan részt vett az antifasiszta ellenállási mozgalomban: 1944 decemberében letartóztatták, majd a háború utolsó napjaiban kivégezték. E röviden összefoglalt életrajz mindaddig pusztán egy katonatudósé, amíg Haushofer a nagypolitika közelébe nem került. Münchenben - nyugállományú tábornokként - geopolitikai intézetet ugyan nem alapíthatott, csak a professzori címhez szükséges venia legendit kapta meg, és kurzusokat tarthatott. Itt tûnt fel hallgatói között az a RUDOLF HESS, aki 1933 után az NSDAP hierarchiájában a második ember lett (WisTRICH, R. 1983). A tanítvány és professzora jó viszonyba kerültek. Az előbbi folyamatosan védelmezte egykori tanárát, aki a geopolitikai eszmerendszerét - az 1946-ban írottak szerint - a társadalom politikai lelkiismeretének is szánta, hogy az olyan világméretű kataklizmák, mint amilyen az első világháború volt, ne ismétlődhessenek meg. Haushofer személyes tragédiája abban rejlett, hogy a politika kényszerének nem mindig tudott ellenállni, és családi áldozatain túl, tanait teljesen kisajátította a pártállam.

A fentiekben leírtakból ered HAUSHOFER máig kétes megítélése, amelyen - geográfiai szempontból - mintegy negyed évszázaddal ezelőtt FRANK EBELING (1994) monográfiája enyhített egy keveset, amennyiben a haushoferi geopolitika térfelfogására fókuszált. Mindemellett a Haushoferrel kapcsolatos szakirodalomban földrajzi munkásságának politikai vetületeit még ma is erősen túldimenzionálják (SCHÖLLER, P. 1957; DiNER, D. 1984; SzILÁGYI I. 2013), geopolitikai tanait pedig egyesen károsnak tartják, esetenként félremagyarázzák, sőt negligálják (MEző F. 1998). A hazai történeti szakirodalomban mintegy két évtizeddel ezelőtt PRITz PÁL $(1996,1999)$ exponálta a Haushofer-kérdést: pusztán politikatörténeti szempontból negatív képet festett a német geopolitikusról. Ezzel egy időben LENDVAI L. FERENC (1997) a közép-európai térrendezéssel kapcsolatos elképzeléseket taglaló munkájában - elismerve Haushofer alkotásainak érdekességét és értékét - azon a véleményen volt, hogy az egész geopolitikai eszmerendszer színvonala ingadozott, majd „lezüllött” (p. 190). O is a hitleri rendszer egyik kiszolgálójaként ábrázolja Haushofert.

E negatív, a jobb esetben is csak felemás Haushofer-megítélések a két világháború közötti évtizedekre, valamint a múlt század negyvenes-ötvenes éveinek fordulójára vezethetők vissza. A távolságtartás, a negatív szakmai vélemények inkább a geopolitikára, mintsem HAUSHOFER személyére vonatkoztak, jóllehet - főleg Németországon kívülrôl nézve a kettő nem volt élesen elválasztható egymástól. Ráadásul a Harmadik Birodalommal szövetséges tengelyhatalmak országaiban sem a haushoferi legitim geopolitika, sem a náci geopolitikával töltött frazeológia nem tudott teret hódítani. (HAUSHOFER, K. 1946) Hazánkban is erős távolságtartás volt a geopolitikával szemben, míg egyéb helyeken vagy teljesen tévesen összemosták a geopolitika két válfaját, vagy csak a legitim geopolitikát tekintették komolyan vehető dolognak. (TELEKI P. 1929; GARZuly J. 1938; WinKLER, E. 1947-1948; Troll, C. 1947) A geopolitikával kapcsolatos egykori fenntartások, ellenérzések azonban megnehezítik KARL HAUSHOFER, a tudós katona megítélését. Kortársai között volt, aki meglátta személyes tragédiáját (TROLL, C. 1947), volt, aki rideg következetességgel igyekezett szétválasztani az eszmerendszer jó és kedvezőtlen sajátosságait, még többen voltak és vannak, akik Haushoferben kizárólag negatív történelmi alakot vélnek felfedezni. E megközelítések mindegyikében van komoly, tudományosan bizonyítható valóság, ám a különböző feldolgozásokban - éppen az egyetlen reálisnak gondolt jellemző igazolása miatt - elvész egy nagyon fontos tényezô: KARL HAUSHOFER szellemi súlya.

Haushofer egyéni vonásai közé tartozott, hogy közvetlen környezetére - ha nem is nyomasztóan - szellemi fölényével hatott. Erre a harcosan antifasiszta világhírú író, STEFAn ZweIG figyelt fel, és benyomásait Haushoferről naplójegyzeteiben is megörökítette (ZweIG, S. 2008). ZwEIG együtt utazott a Távol-Keletre tartó Haushoferrel és fele- 
ségével: nagyon jó véleménnyel volt róluk. Sőt a német katonával töltött idő ébresztette rá az írót: „...az ô példáján láthattam, hogy minden tudomány, még a hadtudomány is, nagyszabásúan müvelve, szükségképpen túllendül a szakterületén, és minden más tudománnyal szervesen érintkezik...” (ZWEIG, S. 2008, p. 241.) A két család a két világháború közötti évtizedekben is kapcsolatot tartott, és ZWEIG már az emigrációban hallotta azokat a pletykákat, amelyek HAUSHOFERt összekapcsolták ADOLF HITLER személyével és környezetével. Kételkedve hallgatta ezeket és a német tábornokról szóló oldalait azzal fejezte be: „történelmi mércével” Haushoferről csak az utókor ítélkezhet majd az „alaposabb dokumentáció segítségével”. Ez a részletesebb, bővebb dokumentáció, amint láttuk, ma már kétségtelenül rendelkezésünkre áll, ám HAUSHOFER árnyalt megítélését - egyoldalúsága miatt - mégsem teszi lehetővé.

A geográfus Haushofert alig-alig ismerjük. A mostani kerek évforduló alkalmat nyújt arra, hogy - a legfrissebb kutatások fényében - visszanyúljunk a legitim geopolitikához, és annak alapján árnyaljuk a Haushofer-képet. E feladat érdekében dolgozatunkban két kérdéskört érintünk. Először áttekintjük KARL HAUSHOFER geopolitikájának tudományos és szellemi forrásait. Másodszor megvizsgáljuk a legitim geopolitikáról vallott értelmezéseit, amelyben kitérünk a geopolitika, valamint a politikai földrajz egymástól való megkülönböztetéséről vallott nézetére is. E két tematika taglalását követóen tudunk állást foglalni a tanulmányunk címében megfogalmazott kérdéssel kapcsolatban. Feladatunk módszertani szempontból megköveteli, hogy a haushoferi geopolitika kezdeti időszakában keletkezett szövegekre, német nyelvú alaptanulmányokra támaszkodva dolgozzunk. Szintén módszertani kérdés, hogy az 1936-1938-ban a geopolitikával kapcsolatos tudományos és politikai-ideológiai vita (TROLL, C. 1947) utáni geopolitikával nem foglalkozunk: azt maga Haushofer sem tartotta legitimnek.

\section{Karl Haushofer geopolitikájának forrásai}

A kétpólusú világrendszer - immár három évtizeddel ezelőtti - megszúnésének, az új hatalmi rend létrejöttének, valamint máig tartó módosulásának hatására a geopolitika és annak olyan rokonterületei, mint a geostratégia, a geoökonómia, a geohistória - hogy csak a legfontosabbakat említsük - virágkorát éli. Ez a láthatóan élénk érdeklődés mára szinte áttekinthetetlen méretú neo- és posztneo geopolitikai szakirodalmat teremtett, amelynek alkotásaiban - a rövid tudománytörténeti előzmények ismertetésekor - vagy az említés, vagy a historiográfiai közhelyek szintjén szólnak KARL HAusHOFERról (KorKISCH, F. 1987; BRILl, H. 1994; CSIZMAdia S. 1998; SzILÁGYi I. 2013). Fokozatosan teret hódított az a szemléletmód, hogy a haushoferi életmú tartalmi feltárása és ismerete nélkül, annak csak a már említett politikai és politikatörténeti vetületeit hangsúlyozzák, ami pusztán a máig érvényes hatásokat igazolja. Így Haushofer esetében elsikkad egyetlen nagyon fontos tényező figyelembevétele: annak kimutatása és tudatosítása, hogy a geopolitika eszmerendszerének egészét Haushofer nem egyik napról a másokra ötlötte ki. A legitim - vagy másként fogalmazva, a klasszikus német - geopolitika fokozatosan, szerves szellemi fejlődés során alakult ki, formálódott. Amit HAUSHOFER és munkatársai mintegy évszázaddal ezelőtt alakítgattak, máig fontos gondolatrendszer lett a világ megértéséhez. Létrejöttében egy sor társadalmi és tudományos folyamat játszott szerepet, és ezek együttes eredője vezette Haushofert eszmerendszere kidolgozásához.

A geopolitikai szakirodalom rendre visszatérő megállapítása, amit Haushofer és munkatársai is erősítettek, hogy geopolitikájuk két forrásból eredt, a svéd RUDOLF KJELLÉN államelméletéből, valamint FRIEDRICH RATZEL antropogeográfiájából és politikai földrajzá- 
ból. A klasszikus német geopolitika alapmúvében, a Bausteine zur Geopolitik(1928) címú tanulmánykötetben - amelyet az eszmerendszer alapvetésének is tekinthetünk - Kjellén és Ratzel munkásságát emelték ki, miközben egyéb - főleg geográfusok - múveit is megemlítették (Haushofer, K.-Obst, E.-Lautensach, H.-Maull, O. 1928). Az akkori szöveg ismeretében, valamint az újabb kutatások - mindenekelőtt CORNELIA LÜDECKE (2019) munkájának - fényében ma már tisztán látható, hogy a klasszikus német geopolitika haushoferi genezisében a társadalmi és szellemi tényezők sokasága játszott szerepet. Ezek közül legfontosabbaknak tekinthetjük a társadalmi környezet geográfiai hatását, és az ettől el nem választható - részben Japánban - szerzett személyes élményeket, az iskolai geográfiai tananyagot, továbbá azt a földrajzhoz nagyon közel álló családi környezetet, amelyben felnőtt, a 19. és a 20. század filozófiai iskoláit, valamint a már említett RUDOLF KJELLÉN és FRIEDRICH RATZEL életmúvét, továbbá az angolszász politikai földrajz és politikatudomány egyes alkotásait.

A társadalmi környezet tekintetében egy közvetlen és egy közvetett hatást kell kiemelnünk. A közvetlen esetében Haushofernek a már említett Japánban tett szolgálati utazása nyújtott olyan tapasztalatokat, amelyek később teljesen szervesültek geográfusi és geopolitikusi munkásságában. A Japánnal kapcsolatos földrajzi kérdések hazatértét követően is folyamatosan foglalkoztatták, Japán és a Távol-Kelet a legkedveltebb kutatási témája maradt. Az ott szerzett, az állam- és birodalmi tér kiépítésével kapcsolatban - tudatos, módszeres megfigyelésekkel - gyûjjött tapasztalatai összefonódtak a saját hazájában észlelt - fiatal korában nyilván nem figyelt - geográfiai folyamattal. Ezt foghatjuk fel a közvetett hatásnak. Amennyiben figyelembe vesszük azt a kronológiai tényt, hogy Haushofer 1869-ben született és 1946-ban hunyt el, akkor látjuk igazán: az ő generációja egy olyan korban élt, amikor a német társadalom számára folyamatos probléma volt az állam- és a hatalmi tér kiépítése, térszervezése. Haushofer életében jött létre a Második Birodalom, majd ennek összeomlását követte a német állam zsugorodása és gyarmatainak elveszítése. Az utóbbi történelmi pillanatában Haushofer ötven éves. Nyugállományú tábornokként éli meg - és ekkor már tudatos megfigyelő és aktív résztvevő - a Harmadik Birodalom létrejöttét, területének expanzióját, hatalmi, birodalmi térszervezését és nem utolsósorban szupremációs terének módszeres kiépítését. E gyakorlati politikai földrajzi tapasztalatok hatását, az irányukban megnyilvánuló egyértelmú fogékonysága, neveltetése, iskolái és gyermekkori élményei erősíthették.

Pusztán a kronológiai adatok alapján HAUSHOFER egy időben nőtt fel a 19. és 20. század fordulóján és a két világháború között a világ élvonalát jelentő német geográfiával, ami esetében az iskolai és a családi környezetében az átlagosnál jóval erősebben testesült meg. HAUSHOFER gyermek- és ifjúkora a földrajztudomány szellemi útkeresésének és németországi intézményrendszere kialakulásának évtizedeire esett (TELEKI P. 1996; LÜDECKE, C. 2019). Születésekor a kialakuló Második Birodalom egyetemein és főiskoláin - más országokhoz hasonlóan - még alig voltak földrajzi tanszékek, és ezek hiányát a szinte gombamód szaporodó földrajzi társaságok és egyesületek pótolták. Beszédes adat ezzel kapcsolatban, hogy 1869-ben Münchenben alakult meg a Német Alpok Egyesület, amelyet hamarosan követett a Bajor Földrajzi Társaság megszületése. Ebben a pezsgó geográfiai közéletben Haushofer apja, MAX HAUSHOFER is döntő szerepet játszott. KARL HAUSHOFER ifjúkorában - e civil szervezetek mellett - három intézményben, a helyi Politechnikumban (a mai Müncheni Műszaki Egyetem elődjében), valamint a Müncheni Egyetemen és a vezérkari tiszteket képző bajor Hadiakadémián alakult ki földrajzi tudományos centrum (LÜDECKE, C. 2019).

KARL HAUSHOFER geográfussá és geopolitikussá válásában ifjúkorában két személy volt nagy hatással. Középiskolájában a Maximilián Gimnáziumban 1884-től - vagyis 
Haushofer tizenöt éves korától - WiLHELM GEIGER (1856-1943), az iráni és az indiai filológia szaktekintélye tanította: ógörögöt, latint és geográfiát oktatott (LÜDECKE, C. 2019; BECHERT, H. 1964). Az utóbbi keretében CARL RITTER tanait közvetítette a tanulók felé, mindemellett ő kelthette fel elsőként a fiatal Haushofer érdek lődését a katonai pálya iránt is. CORNELIA LÜDECKE (2019) legújabb kutatási eredményei alapján ma már tudjuk, hogy GEIGER tudományos hatása KARL HAUSHOFERre jóval túlmutatott egy gimnáziumi tanárén. GEIGER ugyanabban a házban lakott, amelyben a HAUSHOFER családnak volt lakása. Az apa, MAX HAushofer és GeIGER közeli ismeretségben álltak. Az utóbbi a helyi lapokban rendszeresen közölt - ma politikai földrajzinak neveznénk - geográfiai tartalmú írásokat, főleg az ázsiai orosz terjeszkedésről, amelyeket a fiatal Haushofer is olvasott.

A másik meghatározó geográfus a fiatalember életében FRIEDRICH RATZEL volt. Ratzel 1875-től 1886-ig tanított Münchenben, és szintén bejáratos volt a Haushofer családhoz. KARL HAUSHOFER idős korában úgy emlékezett meg róla, hogy a földrajz, a történelem, valamint a hadtudomány szerves egységének gondolatát Ratzel oltotta bele (HAUSHOFER, K. 1944; LÜDECKE, C. 2019; TIETZE, W. 1968-1972). Ratzel közvetlen személyes hatása hat és tizenkét éves kora között érte a fiatal Haushofert, amelyből két év a Geiger-féle hatással párosult. Így a geográfiába - mondhatnánk - belecseperedett HAUSHOFER 1887ben már a történelem és a földrajz felé fokozott érdeklődést tanúsító fiatalként lépett be a bajor hadseregbe, amelynek tagjaként 1895 októbere és 1898 októbere között volt a bajor Hadiakadémia hallgatója. Ebben a tanintézetben WiLHELM GöTz (1844-1911) oktatta a földrajzot és a katonaföldrajzot. Götz már Ratzel tanítványa volt, nála doktorált 1881-ben (TIETZE, W. 1968-1972). Tovább erősítette HAUSHOFERben professzora hatását. Haushofer későbbi életében a GöTz-féle kurzusoknak - még ha nem is közvetlen - nagy hatásuk lehetett, mert részletesen oktatta az akkor a jövő térségének tekintett OroszÁzsiát, Kínát és Japánt is. Ezzel - nyilván akaratlanul - felkészítette KARL HAUSHOFERt a mintegy tíz évvel késóbbi távol-keleti utazására. S ha mindehhez hozzávesszük, hogy a katonai szakma az első világháborút megelőző években fedezte fel magának Ratzel politikai földrajzát (Porro, C. 1910), Haushofer pedig a hadiakadémiai évek alatt ismerkedett meg - apja révén - OsCAR PESCHEL munkásságával (LÜDECKE, C. 2019), és 1913-ban szerzett földrajzi doktorátust, akkor tisztán áll előttünk: KARL HAUSHOFER az első világháborút már a geográfia tudományos múvelésére felkészült hivatásos katonaként kezdte meg.

Az 1914-re földrajzossá nevelődött KARL HAUSHOFER életében az első világháború a katonai pályafutás végét jelentette, de nem tekinthetjük geográfusi fejlődésében, a későbbi geopolitikusi pályájára felkészülésében haszontalan időszaknak. A Nagy Háború éveiben a résztvevők számára egyre reménytelenebbül elhúzódó fegyveres küzdelemról az európai kultúrkör geográfus szakmájában - főleg Németországban - az a vélemény uralkodott, hogy a háború - a világtörténelem első tömegháborúja - méreteiből fakadóan jelentősen növeli a társadalmak földrajzi múveltségét. Egyben földrajzi gyakorlati tapasztalatokhoz juttatja a férfi lakosságot (NAGY M. M. 2006). A kor tisztikarában - és ennek tagjaként KARL HAUSHOFERben is - elmélyítette a katonai tanintézetekben megszerzett földrajzi tudást, gyakorlati élményekkel egészítette ki, alaposan átrostálta és diszciplinálta azt. A háború hadszínterein gyújtött tapasztalatok mélyen hatottak - az egyébként múvészi és irodalmi hajlamokkal is megáldott - német tábornokra. Az itt átéltek, valamint a földrajz és a történelem iránti fokozott érdeklődése együttes hatásának kell tekintenünk, hogy KARL HAUSHOFER geopolitikai rendszerének mind a legitim, mind a későbbi torzult alakjában kitapintható a fokozott figyelem a katonai kérdések iránt. Sőt HAUSHOFER, valamint a nála egy generációval fiatalabb szakmai barátja, OSCAR von NIEDERMAYER a katonaföldrajz megújítója is volt. 
KARL HAUSHOFER geopolitikája, valamint az azt megalapozó földrajzi ismeretrendszere - neveltetéséből és iskolázottságának jellegéből eredően - elsősorban kora német geográfiájára támaszkodott. Ez azonban nem zárta ki az angolszász források ismeretét. Életének utolsó, már említett dolgozatában, az Apologie der deutschen Geopolitikban (1946) írásban is válaszolva kihallgatói kérdéseire, rögzítette, hogy a legitim geopolitika szemléletmódját és módszertanát tekintve megegyezett az angolszász változattal, és abba több nyugati szerzó eszméi is beépültek. Megadta a neveket is: RUdOLF KJELLÉN mellett Semple, Mahan, Brooks-Adams, Joe Chamberlain, Sir Thomas Holdich, Sir Halford MACKINDER, LORD KITSCHENER, J. BowMAN személyét sorolta fel. Világot látott és világjáró tudósként, az egyetemes geográfia szakirodalmát folyamatosan figyelemmel kísérő gondolkodóként - hiszen erre következtethetünk az alkotásaiban található utalások alapján nyilván ismerhette múveiket. Ám hogy ezek valóban a legitim geopolitika elsődleges forrásai is voltak, azzal kapcsolatban már lehetnek kétségeink. Haushofer az apológiai dolgozatát kihallgatóinak pressziója alatt - közvetlenül szívrohama után - vetette papírra, és munkálhatott benne a félelem, a megfelelés kényszere is. Ugyanakkor a klasszikus német geopolitika már említett alaptanulmányában, amely a geopolitika tudománytörténetéról szólt (Haushofer, K.-Obst, E.-Lautensach, H.-Maull, O. 1928) Rudolf KJelléN kivételével aligha találunk nem német előfutárt és szerzőt: geográfiai téren a legitim, a klasszikus geopolitika - a haushoferi megközelítésben - német volt.

Politikatudományi oldalról a legitim geopolitika a svéd RUDOLF KJELLÉN eszmerendszeréből, legfőképpen kulcsmúve német nyelvú kiadásából nőtt ki, amely 1917-ben jelent meg a Második Birodalomban, Der Staat als Lebensform címmel. Ennek második fejezete, amely az állammal mint birodalommal foglalkozik, kapta a geopolitika alcímet. Célszerú hangsúlyoznunk, amire EBELING (1994) is felhívta a figyelmet, hogy a kjelléni államtudományi rendszerben a geopolitika egy nagy szellemi építménynek csak egy fontos része. Egyenrangú a demopolitikával (a népesség és a nemzet kérdései), a kratopolitikával (a kormányzás és az uralom kérdései), az ökopolitikával (a gazdasági élet kérdései), továbbá a szociopolitikával (az állam mint társadalom kérdései) (KJELLÉN, R. 1917; EBELING 1994). Kjellén értelmezésében „A geopolitika az államról mint földrajzi szervezetról vagy térbeli jelenségról szóló tan..”" (KJELLÉN, R. 1917. p. 46), amelyhez hozzáfúzi, hogy az állam vidékként, territóriumként, területként, de a legkifejezőbben birodalomként értelmezendő. HAUSHOFER és munkatársai az első világháborút követően ebből az egységes rendszerből kiemelték, mintegy az első helyre állították a geopolitikát. A többi elemmel is foglalkoztak, de annak alárendelten. A kjelléni geopolitika - fogalmi értelmezése szerint - szinte teljesen megegyezik a 19. és a 20. század fordulójának politikai földrajzával. A svéd tudós a Der Staat als Lebensform címú múvében több helyen is említette az utóbbi meghatározó személyiségét, FRIEDRICH RATzELt: a geopolitikai fejezetet az ő tanai alapján építette fel.

A fentiekből egyenesen adódott, hogy amikor KARL HAUSHOFER és munkatársai elkezdték az első világháborút követően módszeresen felépíteni geopolitikájukat, akkor annak tudományos legitimitását Ratzel antropogeográfiai és politikai földrajzi téziseire alapozták. A Bausteine zur Geopolitikban megjelent tanulmányukban oly módon foglaltak állást, hogy RATZEL ugyan - valószínúleg - nem ismerhette a geopolitika terminus technicusát, de politikai földrajzi munkásságával mégis ő lehetett az első geopolitikus. Mai szemmel nézve RATZEL politikai földrajza nagyon kézenfekvő, jól kezelhető forrása volt a legitim geopolitikának. A német földrajzos a geográfiai jelenségeket, a történelmi eseményeket és folyamatokat, eleve az egész állami élet megnyilvánulásait szintetizálta. Politikai földrajzában (1903) szabatos törvényekké és törvényszerűségekké absztrahálta az állam szinte minden, földrajzi eszközökkel leírható jelenségét. Haushofer geopolitikájának szakmai nyersanyaga RATzELtôl és pályatársaitól származott, ezt fejlesztette tovább, és 
a geopolitikát nem is tekintette egyébnek, mint a politikai gyakorlatban alkalmazott politikai földrajznak. Ennek pedig az lett az eredménye, hogy a politikai földrajz, valamint a klasszikus geopolitika között aligha lehetett és lehet éles határvonalat vonni. A legitim geopolitika tudománytörténete egyben a politikai földrajzé is. ОтTо MAULL - Haushofer egyik munkatársa - az első politikai földrajzi szintézisében (1925) nagyon terjedelmes tudománytörténeti fejezetet írt, amelyben az ókori auktoroktól kezdve mutatja be a fejlödési folyamatot. Az ebben szereplő személyek és múvek - tartalmukat és szemléletmódjukat tekintve, nézetünk szerint - a geopolitika előfutárainak is tekinthetők, amennyiben Ratzel politikai földrajzának is elődjei voltak.

A KARL HAUSHOFERrel foglalkozó szakirodalom régi adóssága a legitim geopolitika filozófiai forrásainak feltárása, ami már amiatt is feltűnő, hogy ez az eszmerendszer - főleg a ratzeli kötődései miatt - felfogható sajátos, geográfiai alapú történetfilozófiaként is. RATZEL antropogeográfiájának és politikai földrajzának e vonásai egyértelmúen kimutathatóak, mint amiként bizonyíthatóak a politikai geográfia ontogenezisében is. A haushoferi rendszer - és ebben a tekintetben meg is haladta Ratzelét - mint földrajzi ontológia szívesen nyúlt történelmi példákhoz, gyakorta történelmi folyamatokat mutatott be a politikai földrajz megközelítésében. Ennek oka nemcsak abban keresendő, hogy földrajz és történelem évszázadokon át szorosan egybetartoztak és éles, végső szétválásuk csak a 19. század folyamán valósult meg. A valódi magyarázat - meglátásunk szerint - mélyen metodológiai. Ratzel és Haushofer tisztán látta, hogy a jelen politikai földrajzi és geopolitikai állapotai értelmezhetetlenek a hozzájuk vezető folyamatok nélkül. E processzusok alapján fogalmazták meg azokat a törvényszerúségeket és az emberi történelemben ismétlődő jelenségeket, amellyel az egész világot leírták.

A fenti gondolkodásmód, valamint a geográfia fejlődéstörténete nyilván megköveteli azoknak a filozófiai hatásoknak az ismeretét is, amelyek befolyásolták egyrészt a geográfia szellemiségét, másfelől a térbeli folyamatokat leíró földrajzi irányzatokat, magát a geopolitikát. Mindehhez hozzá kell füznünk, hogy Ratzel és Haushofer kora a német tudományos életben éppen az az időszak, amikor szellemi téren - mintegy a kor jellemzőjeként minden tudományos kérdéshez filozófiai alapon, vagy filozófiai alapon is illett közelíteni. Hogy ez a szemléletmód és metodológia miként jelent meg a legitim geopolitikában, az még a jövő kutatási feladata. S a hiátus mértékét szemléleti, hogy még EBELING is a „geopolitika ismeretlen gyökereiröl” beszél (EBELING, F. 1994. p. 79.), és csak MoNTESQUIEUt, valamint HENRY BERGSONt említi. Jelenleg kevés ismerettel rendelkezünk arról, hogy a bölcselkedésre, a humán kérdésekre nagyon nyitott KARL HAUSHOFERre milyen filozófiai iskolák és tanok hatottak közvetlenül. Ezzel kapcsolatban érdemes megemlíteni LENDVAi L. FERENC (1996), valamint VinKOVICS MÁRTA (1996) két fontos, filozófiatörténeti tanulmányát. A két dolgozat alapján el kell fogadnunk - pusztán a tudománytörténeti logika alapján -, hogy KANT indirekt hatása érvényesülhetett HAUSHOFER esetében is. E megállapításnál jóval tovább jutott LENDVAI L. FERENC (1996), aki filozófiai alapon vizsgálva a geográfia ontogenezisét arra az eredményre jutott, hogy annak a modern korban „...három nagy paradigmája volt: Ritter »filozófiai«, Ratzel »politikai« és Hettner »chorológiai« földrajztudománya (és ezek különféle variációi), amelyek után most egy ökológiai földrajztudomány látszik kialakulni...” (LENDVAI L. F. 1996. p. 119.).

Lendvai foglalkozott Haushoferrel is, ám Ratzelhez hasonlóan az ő esetében sem adta meg a geopolitikát determináló filozófiai irányzatokat, míg a korábbi időszakhoz tartozó CARL RITTER esetében - egyebek mellett - Kantot, Hegelt, valamint Herdert nevesítette. A földrajzi paradigmák lajstromában Haushofernek - véleményünk szerint - Ratzel politikai földrajzi paradigmájában van a helye. Ebből ered, hogy a klasszikus német geopolitika filozófiai forrásait a Ratzel világképét determináló, valamint a Haushofer kortársai közé 
tartozó filozófusok és politológusok munkáiban lelhetjük meg. Ugyanakkor - követve Lendvai tudománytörténeti fejtegetéseinek gondolatmenetét - Haushofer geopolitikáját bátran beleilleszthetjük a történetfilozófia szellemtörténetébe még akkor is, ha a magyar szerző kimondottan negatív véleményt mond a német tábornokról, és miközben elismeri múveltségét, valamint sokirányú érdeklődését, kétségbe vonja tudományos képzettségét. A HAUSHOFER tanulmányairól és neveltetéséról, iskolázottságáról rendelkezésre álló adatok alaposan ellentmondanak ennek a megállapításnak.

\section{Karl Haushofer geopolitikája és a politikai földrajz}

Amennyiben KARL HAUSHOFER életét - a geográfiához és a geopolitikához való viszonyulása alapján - szakaszokra bontjuk, akkor az két egymástól jól elkülöníthető etapra tagolható, amelyeket az első világháború évei választanak el egymástól. Az első életszakasz, a geográfiai és geográfusi környezetben történő nevelődés, majd tapasztalatszerzés, valamint az ismeretek diszciplinálása mintegy fél évszázadot tölt ki. A Németországon is végigsöprő baloldali és szélsőbaloldali mozgalmak, forradalmak, majd az erre társadalmi válaszul adott jobboldali - erőszaktól sem mentes - reakciók, az addig uralkodó társadalmi berendezkedés teljes összeomlása, valamint a német nagyhatalmiság megrendülése ötven éves kora körül érte Haushofert. Jóllehet a fegyveres erőktől nyugdíjazzák, de a szellemi életben éppen ekkor nyíltak meg számára a nagy lehetőségek. KARL HAUSHOFER pont abban az életkorban járt, amikor - igaz a társadalmi viszonyok és a korszellem kényszere alatt - még nagyot léphetett: nem elhagyva a korábbit, sôt megórizve azt, új életet, új foglalkozást kezdhetett. Ez lehetett a geopolitika felé történő tudatos fordulásának egyik személyes indítéka. A másik a Köztes- és Közép-Európára kiterjedő térbeli átrendeződéssel párhuzamosan kibontakozó keserűség érzése: a háborúban hozott hatalmas áldozatok ellenére - hiszen egyedül a Második Birodalom a nagy küzdelem során mintegy 13,25 millió katonát állított hadba, amelyből 1,85 millió soha sem tért vissza, további 4,25 millió pedig megsebesült vagy még rokkant is lett (KLEINDEL, W. 1989) - elszenvedett kudarc társadalmi szintű deprimációja. A második, a geográfusi-geopolitikusi életszakasz ezekkel a kataklizmákkal kezdődik.

Az európai kultúrkörben az első világháború több együtt élő generáció nyomasztó, az egész kultúrát és szellemi életet átalakító tömegélménye lett. Mind a győztes, mind a vesztes társadalmak világában elkezdődött egy nagyon sajátos - a tudományoktól a publicisztikán át egészen a múvészetekig és a politikai demagógiáig ívelő - oknyomozás. Szinte a végletekig leegyszerúsítve az érdekelte az embereket: a századfordulót megelőző lelkes, optimista, magában meggyőződésből hívő, alapvetően humanista és modernizációs gondolkodástól miként jutottak el 1914-ben a háborút szinte kikényszerítő szellemi állapotig, a tömegpszichózisig, és miként fordulhatott elő a Nagy Háború kataklizmája. A központi hatalmak vesztes társadalmaiban pedig még ennél is kézzelfoghatóbb, az emberekre intenzívebben ható kérdés merült fel: mire volt a hatalmas áldozat, mi volt a nagy küzdelemben elszenvedett vereség oka, hiszen a háború folyamán pusztán katonatechnikai szempontból több alkalommal is kéznyújtásnyira volt a győzelem (RAKOLCAI L. 1937).

Haushofer eszmerendszerének létrehozása a fenti folyamat szerves része volt, amelyet a német geográfus és tábornok élete utolsó pillanatáig - szinte - büszkén vállalt. A már említett, a kihallgatói ösztönzésére írott, Apologie der deutschen Geopolitik (1946) címú tanulmányának harmadik pontjában nyújt magyarázatot annak genezisére. Tudománytörténeti szempontból kiemelendő, hogy a legitim geopolitika létrejöttét egyben apológiájának is tartotta. A genezis évszámát 1919-re tette, amikortól az főiskolai tantárgyként megjelent. 
Amennyiben elfogadjuk ezt az adatot, és kronológiailag a már említett 1936-1938 között lezajlott vitához, valamint Haushofer 1938-ban bekövetkezett politikai kegyvesztéséhez mérjük, úgy a legitim német geopolitika fennállásának idótartama rövid két évtized lehetett. Haushofer az Apológia létrejöttét a német társadalmat ért első világháborús traumával magyarázta. A vereség hatására három geopolitikai kérdéskör került előtérbe: az élettér, a határok, valamint az óceáni és kontinentális geopolitika problémája. Mai szemmel nézve mindhárom olyan volt, amely a német társadalom tudatában már 1914-et megelőzően mélyen gyökerezett, a fojtogató földrajzi bekerítettség érzetével függött össze. Élete utolsó tanulmányában elmondta azt is, hogy az első világháborút követô „élettér-felosztás", a területi feldarabolás tarthatatlanságának érzése alól nem vonhatta ki magát ő sem. Ez vezetett később a határokról szóló könyvének (1927) megírásához, amelyről ma már tudjuk: az államhatárok földrajzi jelensége szakirodalmának egyik alapmúve. Ugyancsak az Apológiában mondta el HAUSHOFER - mintegy erkölcsi fölényét hangsúlyozva -, hogy „a nemzet normálisan érzó” tag jaként a tudományos objektivitás talaján álló tudós ember „,legitim módon szerzett ismereteit” népe szolgálatába kellett állítania. Ekkor vállalta azt is, hogy még a múlt század húszas-harmincas éveinek fordulóján is teljesen elmosódott a határ a „tiszta és az alkalmazott tudomány között” és ezen a határon olykor maga is átcsúszott (HAUSHOFER, K. 1946. pp. 19-20.). Mélyebb filológiai és textológiai kutatást igényelne Haushofer utóbbi kijelentésének értelmezése, mert a legitim geopolitika keletkezésének körülményei, valamint a német társadalom mentális gyógyításának szándéka indokolja ezt az átsodródást az egyébként egyáltalán nem káros alkalmazott tudomány területére. A káros az lehetett, amikor HAUSHOFER a geopolitikát - célját tekintve - túl közel vitte a politikához, és a kettő közötti határon átsodródott.

Ennek a tudományos túlzásnak a veszélye már benne rejlett a haushoferi legitim geopolitika értelmezésében is. A Bausteine zur Geopolitikban Haushofer foglalta össze a geopolitika lényegét és mint tudományos ismeretrendszernek céljait (HAUSHOFER, K. 1928a). Az itt publikált tanulmány a legitim geopolitika alapvetésének lényeges dokumentuma, amelynek tartalma bővebb a puszta fogalmi meghatározásnál. Egyrészt foglalkozik néhány szakirodalmi kérdéssel, a geopolitika genezisének több lényeges vonásával, tudományos előzményeivel - itt említ nyugati és távol-keleti szerzőket is -, és ezekkel kapcsolatosan fogalmazza meg saját tézisét. Az egyébként irodalmi stílusban keletkezett textus fontos tartalmi eleme - ami majd egészen HAUSHOFER haláláig felbukkan múveiben -, hogy a politika folytatása bármennyire praktikus alapon történik is, nem lehetséges földrajzi, eleve tudományos alapok nélkül. A politika szakmai megalapozottságát - mind a tömegek, mind a politikusok szintjén - a geográfiától várta, amely - tegyük hozzá - éppen az első világháború hatására ébredt rá saját integráló jellegére (TELEKI P. 1996). Haushofer ebben az írásában, amely a geopolitika fogalmi fejlődését taglaló, közös szerzőség alatt megjelent tanulmány (HAushofer, K.-OBSt, E.-LAutensaCH, H.-Maull, O. 1928) után szerepelt a Bausteine zur Geopolitikban, nem tér el az annak végén összegyújtött fogalmi értelmezés legelterjedtebbjétől: „...A geopolitika a politikai folyamatok földhözkötöttségének tana...” (Haushofer, K.-ObSt, E.-LAutensach, H.-MAull, O. 1928. p. 27.). Ennek elfogadásával és hátterének magyarázatával azonban túl is lép KJELLÉN geopolitikai felfogásán, amelyben - mint láttuk - az még pusztán a ratzeli értelmezés politológiai átvétele volt, amennyiben a svéd gondolkodó az államot földrajzi jelenségként ragadta meg. A két fogalom tartalmi eltérése szinte alig észrevehető - két nagyon jól hangzó mondatról van szó -, ám ez a különbség a haushoferi értelmezésben nagyon fontos tartalmat takar. A geopolitika lényegéről szóló, saját neve alatt publikált tanulmányának már az elején rögzíti Haushofer (1928a), hogy a geopolitika a politika múvészetét gyakorlati úton folytató vezetôk nevelésének jogára is igényt formál. Ezért a történelmen, a politikai földraj- 
zon, a közlekedés- és gazdasági, valamint a kultúr- és védelmi (katonai) geográfián kell leginkább alapulnia, amelyhez még a jogtudomány is társulhat. Szerző- és munkatársára, OTTó MAULLra hivatkozva itt is kijelenti, hogy a geopolitika nemcsak politikai geográfia, hanem annál sokkal több (HAUSHOFER, K. 1928a).

A kérdés már csak az: mi volt ez a Haushofer által említett több. Ennek megfogalmazásához viszonylag terjedelmes szakirodalmi áttekintést nyújt - bizonyítja ezzel az utókornak, hogy az ő nevéhez kapcsolódó (legitim) geopolitika eszmerendszere geográfusok csoportjának munkájaként kristályosodott ki -, majd ennek alapján jelenti ki: olyan gyakorlati ismeretek halmaza legyen, amely mindig készen áll a politikai döntések meghozatalához. Ebből a napi gyakorlati igényből ered, hogy a geopolitika szélesebb alapokon nyugszik - mondja Haushofer (1928a) -, mint a politikai földrajz. A geopolitika legfontosabb feladatát itt Haushofer a földrajzi alapon történő előrejelzésben látja a politika számára. A feladatot a geopolitika csak akkor tudja teljesíteni, ha maga is tudománnyá válik. A politikai döntések előkészítése és a folyamatok, események előrejelzése - így Haushofer - azonban széles körű népszerúsítő - mondhatnánk - efemer irodalmat is igényel. Ennek indokát a folytonos tudományos naprakészségben látta, ám - és ez ma már elmondható - ily módon HAUSHOFER beemelte a legitim geopolitikába a jó tollú, ám geográfiailag képzetlen zsurnalisztákat és a múkedvelő amatőr geopolitikusokat is. Meglátásunk szerint ezzel, már a húszas évek második felében, jóllehet nem tudatosan, HAUSHOFER is elősegíthette a legitim geopolitika későbbi felszámolását, mert ezek az epigonok bontották le annak határát.

A Bausteine zur Geopolitik megjelenésekor, 1928-ban, a haushoferi geopolitika már közel egy évtizede létezett, és legfontosabb orgánuma, a Zeitschrift für Geopolitik az ötödik évfolyamánál tartott. Lapszámai a benne megjelent írásokat tekintve nem sokban különböztek bármely németországi földrajzi folyóirat politikai földrajzi tanulmányaitól. Eleve az egész geopolitikai ismeretrendszer nehezen volt elválasztható a politikai földrajztól, még ha Haushofer és munkatársai - elsősorban a politika számára - alkalmazott, vagy ha úgy tetszik, gyakorlati politikai geográfiát is láttak benne. A szétválasztás szükségességét maga Haushofer is megérthette, és ez lehetett az oka, hogy a Bausteine zur Geopolitik címú kötetbe, utánközlésként belekerült az eredetileg a Drygalski professzor köszöntésére készült tanulmány is (HAUSHOFER, K. 1928b) a politikai földrajz, valamint a geopolitika kapcsolatáról. A tudományos szempontból az elóbb értelmezett dolgozathoz képest sokkal pontosabban fogalmazott szöveg lényegi mondanivalója: a geopolitika „...rokon az alkalmazott politikai földrajzzal, de mégsem teljesen ugyanaz...” (HAUSHOFER, K. 1928b). Ismét beleütközünk a már látott valamivel több, mint a politikai földrajz jelenségébe. De miben áll ez a többség? Erre a kérdésre Haushofer oly módon igyekszik - ha nem is választ - magyarázatot adni, hogy a politikai földrajzot a geopolitikával együtt a térbeli jelenségek tudományának tartja, amely arra irányuló felismeréseket szerez és tesz közzé: a hatalmat földrajzilag miként kell megszerezni, megtartani a térben. Ma azt mondanánk erre: miként célszerú megvalósítani a térszervezést. Ezzel a feladattal kapcsolatban HAUSHOFER követelményeket fogalmazott meg, amelyek - mellőzve részletes tartalmi ismertetésüket - a geopolitikát alkalmazott politikai földrajzként az államtudományok felé tolja el. Haushofer és munkatársainak korábbi és későbbi alkotásaiban - részben Kjellén, részben Ratzel hatására - rendre feltúnik az a nézet, hogy a geopolitikát minden erôs földrajzi vonása és domináns geográfiai tartalma ellenére éppen a politikát támogató jellegéből eredően az államtudományokhoz sorolták. A tudományrendszertani értelmezéssé váló, a politikai földrajztól való elkülönítésre irányuló próbálkozások a legitim geopolitikában rendre kudarcot vallottak. Mint amiként e problémát HAUSHOFER sem volt képes egyértelmúen megoldani a Bausteine zur Geopolitikban közölt tanulmányában. Pontosabban a kérdés feloldását itt is a politikai földrajzból kinőtt geopolitikának a politikához történő 
túlzott közelítésével sikerült valamelyest feloldania. E megoldás - Haushofernek a szöveg minden során érződő hatalmas múveltsége és szakmai tudása ellenére - sem lett tökéletes. Egyfelől azért, mert végül a geopolitikát mégis csak meghagyta a geográfia keretén belül, másfelől azért, mert a túlzott gyakorlatiasságra való törekvés - főleg mai szemmel olvasva a textust - veszélyeztette a geopolitika tudományosságát. A legitim geopolitikára nézve ez egy évtized múlva végzetes lett.

\section{Összegfoglalás}

Tanulmányunk fejezeteiben kora néhány szignifikáns jellemzőjén túl oly módon emlékeztünk meg KARL HAUSHOFERról, hogy életrajzán keresztül bemutattuk geopolitikai eszmerendszerének főbb forrásait, valamint a geopolitikáról alkotott felfogását és annak elválasztását a politikai földrajztól. A szakirodalmi és forráshasználati szempontból kétes hitelű, ám mégis széles körben elterjedt nézetekkel szemben a legújabb kutatási eredmények és az egykori eredeti szövegek felhasználásával igyekeztünk bizonyítani, hogy a haushoferi geopolitika forrásai jóval bővebbek voltak, mint RUDOLF KJELLÉN és FRIEDRICH RATZEL munkássága. Jóllehet inkább áttételesen, de erős hatás mutatható ki - főleg gyermek és ifjúkorában - CARL RITTER felől is. Dolgozatunk legfőbb mondandója, hogy KARL HAUSHOFER munkásságára, egész életmúvében olyan sokrétú hatás érvényesült, amely eleve predesztinálta, hogy egy nagyon sok tudományból táplálkozó eszmerendszert, a geopolitikát teremtse meg. Ezt az eszmerendszert csak az első világháborút követố társadalmi és politikai közegben lehetett létrehozni, amivel azt is állítjuk: maga a kor és szellemisége gyakorolt olyan kényszerítő erőket, amely a geopolitikát és vele Haushofert is a Harmadik Birodalom ideológiája felé terelte. Ennek nyomai Haushofernek a geopolitikai alapvetésében is tetten érhetőek, jóllehet a kortársak közül ezt akkor még alig láthatta valaki.

A tanulmányunk címében megfogalmazott kérdésre adandó válaszhoz az visz közelebb, ha az eddig elmondottak alapján szólunk arról is: mennyiben volt HAUSHOFER geográfus? Végzettségét tekintve - miután geográfiából szerzett tudományos fokozatot - annak kell tartanunk. A kérdés azonban nem, vagy nem csak végzettségre utal. A HAUSHOFERrel kapcsolatos negatív vélemények éppen a szakmai hozzáértését vonják kétségbe. Nincs igazuk, mert megállapításukkal Haushofer kortárs geográfusait is negligálják. Ratzel és Haushofer, Drygalski generációjában nagyon sok olyan neves földrajzost találunk, akik autodidakta módon szerezték geográfiai ismereteiket. Haushofernél ez - mint láttuk egészen sajátosan alakult. A korszak igazi geográfusainak életmúvében a világ járás során szerzett tapasztalatok beépültek a földrajzi ismeretrendszerbe, és ily módon egy magasabb rendú tudás jött létre. HAUSHOFER esetében is ez történt. A civil és a katonai tanintézetekben szerzett tudás a japáni tapasztalatokkal, majd a világháborús élményekkel bővült. Az utóbbiak miatt nem illeszkedik HAUSHOFER teljesen kora geográfusai közé. Részben a katonai szakmájának is köszönhető, hogy múveltsége és világlátása több jó nevú kortárs geográfusénál szélesebb körû volt. Ennek ellenére geográfusnak tekintendő, de olyannak, aki tudásának, az átlagnál jobb képességeinek köszönhetôen megteremthetett ugyan egy eszmerendszert, tudományosnak induló szakterületet, de kora szellemisége és történelmi folyamatai ôt is determinálták.

NAGY MiKLÓs MiHÁly

Nemzeti Közszolgálati Egyetem, Budapest

szentvazul@gmail.com 
DÖVÉNYI ZOLTÁN

Pécsi Tudományegyetem, Pécs

dovenyiz@gamma.ttk.pte.hu

\section{IRODALOM}

Bechert, H. 1964: Wilhelm Ludwig Geiger. - In: StollberG - Wernigerode, O. (szerk.): Neue deutsche Biographie: sechster Band. Duncker\&Humblot, Berlin: pp. 142-143.

BRILL, H. 1994: Geopolitik heute: Deutschlands Chance? - Ullstein GmbH. Frankfurt am Main - Berlin: 240 p.

Csizmadia S. 1998: A geopolitika mint a nemzetközi kapcsolatok elemzésének módszere. - Külpolitika 4. (új évf.), 1. pp. 3-31.

Diner, D. 1984: „Grundbruch des Planeten”: zur Geopolitik Karl Haushofers. - Vierteljahreshefte für Zeitgeschichte 32. 1. pp. 1-28.

EbELING, F. 1994: Geopolitik: Karl Haushofer und seine Raumwissenschaft 1919-1945. - Akademie Verlag, Berlin: $272 \mathrm{p}$.

GARZUlY J. 1938: Geopolitika. - Magyar Szemle 12. 4. pp. 354-361.

HAUSHOFER, K. 1927: Grenzen in ihrer geographischen und politischen Bedeutung. - Kurt Vowinckel Verlag, Berlin: $350 \mathrm{p}$.

Haushofer, K. 1928a: Grundlagen, Wesen und Ziele der Geopolitik. - In: Haushofer, K. -Obst, E.-LAUTENSACH, H.-MAUll, O. (szerk.): Bausteine zur Geopolitik. Kurt Vowinckel Verlag, Berlin-Grunewald. pp. 29-48.

Haushofer, K. 1928b: Politische Erdkunde und Geopolitik. - In: Haushofer, K.-Obst, E.-Lautensach, H.-Maull, O. (szerk.): Bausteine zur Geopolitik. Kurt Vowinckel Verlag, Berlin-Grunewald. pp. 49-77.

HAUSHOFER, K. 1944: Friedrich Ratzel im raumpolitischen Umbruch seiner und unserer Zeit. - Geographische Zeitschrift 50. 3-4. pp. 81-87.

Haushofer, K. 1946: Apologie der deutschen Geopolitik. - In: Walsh, E. A. (szerk.): Wahre anstatt falsche Geopolitik für Deutschland. Verlag G. Schulte - Bulmke, Frankfurt am Main: pp. 18-27.

Haushofer, K.-OBst, E.-LautensaCh, H.-Maull, O. 1928: Über die historische Entwicklung des Begriffs Geopolitik. - In: UôK. (szerk.): Bausteine zur Geopolitik. Kurt Vowinckel Verlag, Berlin-Grunewald. pp. 3-28.

Haushofer, K.-Obst, E.-Lautensach, H.-Maull, O. (szerk.) 1928: Bausteine zur Geopolitik. Kurt Vowinckel Verlag, Berlin-Grunewald. 348 p.

KJELlÉn, R. 1917: Der Staat als Lebensform. - S. Hirzel Verlag, Leipzig. 235 p.

KLEINDEL, W. 1989: Der Erste Weltkrieg: Daten-Zahlen-Fakten. - Österreichischer Bundesverlag. Wien. 295 p. $+32 \mathrm{t}$.

KORKISCH, F. 1987: Geopolitik - Geostrategie - Geoökonomie. - Österreichische Militärische Zeitschrift 25. (új évf.) 1. pp. 18-27.

LendVAi L. F. 1996: A földrajz filozófiája mint történetfilozófiai probléma. - Magyar Filozófiai Szemle 1-3. pp. 95-125.

LENDVAi L. F. 1997: Közép-Európa koncepciók. - Áron Kiadó, Budapest. 308 p.+11 t.

LÜDECKE, C. 2019: Militärische und zivile Geographie: von Carl Ritters Geographie in Berlin bis zu Karl Haushofers Geopolitik in München. - Books on Demand, Norderstadt. 236 p.

MÄrz J. 1969: Karl Ernst Haufhofer. - In: Stollberg-Wernigerode, O.-Bussmann, W. et al. (szerk.): Neue Deutsche Biographie: achter Band, Duncker und Humblot, Berlin: pp. 121-122.

Maull, O. 1925: Politische Geographie. Gebrüder Borntraeger, Berlin: XV + 743 p.

MEző F. 1998: A geopolitika kialakulása és korai válsága. - Debreceni Szemle 6. 2. pp. 193-221.

MEZő F. 2006: A geopolitika formaváltozásai. - Politikatudományi Szemle 15. 4. pp. 75-107.

NAGY M. M. 2006: Kis magyar hadelmélet: hadügy, hadelmélet, földrajz és geopolitika kapcsolata. - Zrínyi Kiadó, Budapest. 224 p.

NAGY M. M. 2019: A klasszikus geopolitikáról. - Geopolitikai Szemle 1. 1. pp. 149-164.

NAGY M. M.-DövÉNYI Z.-BÉKÉsi L. 2019: A klasszikus geopolitika Magyarországon. - In: PAP N.-LiLióN, D.-SzÁNTó Á. (szerk.): A tér hatalma - a hatalom terei: tanulmánykötet a 70 éves Szilágyi István profeszszor tiszteletére. Pécsi Tudományegyetem Természettudományi Kar, Pécs. pp. 79-90.

Porro, C. 1910: Aufgaben und Methoden der Militärgeographie I-II.- Petermanns Geographische Mitteilungen. 59. 1. Beilage pp. 53-55, 2. Beilage pp. 116-118.

Pritz P. 1996: A Haushofer-jelenség. - In: IzsÁk L.-STEMLER Gy. (szerk.): Vissza a történelemhez...: emlékkönyv Balogh Sándor 70. születésnapjára. Napvilág Kiadó, Budapest. pp. 279-292.

PRITZ P. 1999: Pax Germanica: német elképzelések Európa jövőjéről a második világháborúban. - Osiris, Budapest. 302 p. 
RAKOLCAi L. 1937: A világháború sorsdöntő órái. - Magyar Katonai Szemle 7. 12. pp. 6-21.

Ratzel, F. 1903: Politische Geographie oder die Geographie der Staaten, des Verkehres und des Krieges [2. umgearbeitete Auflage]. - Oldenbourg, München-Berlin: XVIII + 838 p.

SEIDT, H.-U. 2002: Berlin, Kabul, Moskau: Oskar Ritter von Niedermayer und Deutschlands Geopolitik. Universitas, München. 510 p. $+16 \mathrm{t}$.

SCHÖLLER, P. 1957: Wege und Irrwege der politischen Geographie und Geopolitik. - Erdkunde 11. 1. pp. 1-20.

SZILÁGYI I. 2013: Geopolitika. - IDResearch Kft. - Publikon Kiadó, Pécs. 254 p.

Teleki P. 1929: Hennig R: Geopolitik. - Földrajzi Közlemények 57. 1-5. pp. 46-47.

TELEKI P. 1996: A földrajzi gondolat története - Kossuth Könyvkiadó, Budapest. 193 p.

Tietze, W. (szerk.) 1968-1972: Westermann Lexikon der Geographie. I-V. Georg Westermann Verlag. Braunschweig. $5 \mathrm{db}$.

Troll, C. 1947: Die geographische Wissenschaft in Deutschland in den Jahren 1933 bis 1945. - Erdkunde 1. 1. pp. 3-48.

VINKOviCs M. 1996: Kant mint a klasszikus geográfia előfutára. - Magyar Filozófiai Szemle 40. 1-3. pp. 81-93.

WiNKLER, E. 1947-1948: Karl Haushofer und die deutsche Geopolitik. - Schweizer Monatshefte 27. 1.pp. 29-35.

Wistrich, R. 1983: Wer war wer im Dritten Reich: Anhänger, Mitläufer, Gegner aus Politik, Wirtschaft, Militär, Kunst und Wissenschaft. - Harnack, München. 319 p.

ZwEIG, S. 2008: A tegnap világa: egy európai emlékezései. - Európa Könyvkiadó, Budapest. 549 p. 